$$
\begin{gathered}
\text { カベルネ・ソービニヨン及びマスカット・ベリー } \mathrm{A} \\
\text { 赤ワインの熟成中における色調の変化 }
\end{gathered}
$$

I. 色素パラメータのスペクトル分析

\author{
横 塚 弘 毅 \\ <山梨大学発酵化学研究施設>
}

\author{
平成 6 年 8 月 25 日受理
}

\begin{abstract}
Changes in Color during Aging of Cabernet Sauvignon and Muscat Bailey A Red Wines : I. Spectral Analysis of Pigment Parameters
\end{abstract}

\title{
Koki YoKoTsuKa
}

(The Institute of Enology and Viticulture, Yamanashi University, 13-1 Kitashin-1-chome, Kofu, Yamanashi 400, Japan)

\begin{abstract}
Seventeen Cabernet Sauvignon and 16 Muscat Bailey A red table wines were made from 1968 to 1993 and stored in $1,8 \mathrm{l}$ glass bottles at $15^{\circ} \mathrm{C}$ for periods varying from 8 months to 25 years, 8 months. Selected vintages were analyzed for color both spectrophotometrically and sensorily. In the 14 different vintages of the two varieties analyzed, good correlations were observed in wine color at wine $\mathrm{pH}$, wine color in acid, color density, polymeric pigment color, and color hue between analysis performed in 1992 and 1994. This means that the extent of changes in the pigment parameter obtained in these 2 years were similar with different vintages and with different degrees of aging. The color of aged wines made prior to 1987 appeared to be primarily due to polymeric prigments, whereas that of aging or young wines made between 1989 and 1993 seemed to be fundamentally due to a mixture of monomeric, oligomeric and polymeric anthocyanin pigments. Considering this together with the color hue, red wines of the two varieties appear to reach an "aged state" within 5 years, at least in regard to the color of the wine. Young wines of the two varieties received better sensory evaluation than aged wines. Visual assessments of color correlated signiflcantly with taster's assessment of overall quality and with the instrumental measurements of pigment parameters at wine $\mathrm{pH}$ such as wine color, color density and polymeric pigment color.
\end{abstract}

Key words : 赤ワイン・熟成・アントシアニン

\section{緒言}

赤ブドウ果皮から醸し発酵中に抽出されたアントシア ニン色素によって着色した若い赤ワインは, 発酵終了後 の澱引き, 澱下げ, さらに貯蔵などの色々なプロセス中 に, その色調を紫赤色から深紅色あるいは赤色, またレ ンガ色へと変化させる。若い赤ワインの色調は主として アントシアニンモノマーに由来し，そのワインの熟成が 進むにつれてモノマーが減少する。モノマーは酸化的に 重合して色素オリゴマーやポリマーとなり, それらの割 合は熟成が進むにつれて増加し, 化学的に安定した状態 となることが知られている。
高速液体クロマトグラフィーの発展によって若い赤ワ インの色調を決定しているアントシアニンモノマーの組 成の解明は非常に進歩したが，赤ワインの色調を全体的 に説明するには，依然としてワインを直接にスペクトル 分析することが有用である。特に, 熟成した赤ワイン中 の色素オリゴマーやポリマーはそれらの化学構造が十分 に解明されて抢らず，またとれらを相互に分離する手段 が知られていないことから，スペクトル分析が最も重要 な分析手段となっている。

SOMERS and EVANS ${ }^{1,2)}$ は, 若いオーストラリア赤ワ イン（カベネル・ソービニョン, シラー）を種々の条件 下で $520 \mathrm{~nm}$ と $420 \mathrm{~nm}$ の吸光度を測定した結果, 赤 
横塚 : カベルネ・ソービニヨン及びマスカット・ベリーA赤ワインの熟成中にお括る色調の変化 I .

ワインの品質と color density $\left(\mathrm{A}_{420}+\mathrm{A}_{520}\right)$ あるいはア ントシアニンのイオン化の度合との間に高い相関性が あることを示し，また JACKSON ら゙は，ボージョレー の若いがメイワインについての同様なスペクトル分析か ら, ワインの overall quality（カラー, アロマ及びフレ 一バーの合計）と種々の色素パラメータとの間に直線的 な相関関係を認めた。

本研究でも, 彼らのスペクトル分析法 ${ }^{1 \sim 4)}$ に基づいて 日本産赤ワインの色調の分析を試みた結果，ワイン製造 後 2,3 年の非常に若い赤ワインについては, 彼らとほ ぼ同様な結果となった。しかし，熟成中あるいは熟成し た赤ワインの色調の解析にスペクトル分析法が適用でき るか否かは今まで十分に検討されておらず，また，日本 産ブドウから製造した赤ワインに関しては，熟成したワ インは㧍ろか, 若いワインの色調に対しても十分な研究 はなされていない。本研究は，ヨーロッパ品種の中で日 本での栽培が比較的に容易之言われているカベルネ・ソ 一ビニヨンブドウと日本の代表的な赤ワイン用品種であ るマスカット・ベリーAブドウから常法従って製造し た赤テーブルワインの色調の熟成中の変化をスペクトル 分析することを目的とした。

\section{実 験 方 法}

\section{1. 赤ワインの製造と貯蔵}

山梨大学発酵化学研究施設付属育種試験地で生育させ たマスカット・ベリーAとカベルネ・ソービニヨンブド ウを 1979 年, 1980 1993 年の 10 月初旬〜中旬に 16 〜 18 Brix の糖度になった時点で収穫した。1968 年と 1975 年のブドウは山梨県勝沼町から同様な糖度のもの を購入した。これらのブドウを用いて，常法に従って赤 テーブルワインの製造を行った。

収穫したブドウ果実 ( 1 ロット $300 \mathrm{~kg}$ で 2 回醉造) をローラータイプ除梗破砕機（MABILLE 社製，タイプ 46）で除梗破砕し，得られたマストにピロ亜硫酸カリウ ムを二酸化イオウにして $50 \mathrm{mg} / \mathrm{l}$ の濃度になるように加 えた後, ステンレススチール製タンク中, 室温で一夜放 置した。

Saccharomyces cerevisiae W $3^{5)}$ の酒母を $2 \%(\mathrm{v} / \mathrm{v})$ 添加し, 室温で発酵させ, 発酵マスト中のアルコール濃 度を経時的に測定した。アルコール濃度が $7 〜 8 \%$ にな ったとき（酒母添加後約 1 週間), バスラン型圧搾機 (3 $\mathrm{HL}$ タイプ）で圧搾して液体マストを得た。年によって 違うが, $300 \mathrm{~kg}$ のブドウから 185〜220l のマストが得 られた。これらの発酵マストに酒母添加前のマストの糖 度に換算して $23^{\circ}$ Brix になるように砂糖を添加後, 炭 酸ガスの泡が認められなくなるまで発酵を続けた。発酵
が終了してから一週間後にピロ亜硫酸カリウムを二酸化 イオウにして $75 \mathrm{mg} / l$ の濃度となるように添加して一夜 放置した。これを連続遠心機（H-600S タイプ，国産遠 心機株式会社）を用いて，9,700 $\times \mathrm{g}, 50 \mathrm{l} / \mathrm{hr}$ の送液量で 遠心分離を行い，得られたワインをセルロースとケイソ ウ土からなるノンアスベスト濾過板（厚さ 2〜 $4 \mathrm{~mm}$, 大 きさ $200 \times 200 \mathrm{~mm}, \mathrm{NA}-16$ タイプ，アドバンティック 東洋株式会社）を 13 枚使用して濾過した。このワイン にピロ亜硫酸カリウムを加え, 翌日に遊離亜硫酸を測定 して 40〜 $50 \mathrm{mg} / l$ に達しない場合には再びピ口亜硫酸カ リウムを添加して, 上記の濃度範囲に遊離亜硫酸が存在 するように調整した。ワインを $1.8 l$ 容ガラスボトルに 詰め, 王冠をし, 横倒しして, 分析するまで約 $15^{\circ} \mathrm{C} の$ 地下唄蔵庫に保管した。

毎年のワインの製造にあたって, ブドウの前処理, 酒 母の調製, 発酵条件, 発酵後の処理, 貯蔵の条件などは できるだけ同じになるようにし，ワインへのベントナイ トやゼラチン添加などによる澱下げ処理や木樽内貯蔵な どは行わなかった。

\section{2. ワインの一般分析}

各ワインの第 1 回目の分析は乞の製造開始（酒母添 加）から約 8 カ月経った時点で行った。すべての分析は 少なくても 2 回, 異なったボトルのワインについて行 い, 得られた分析値はそれらの平均值で示した。製造し た赤ワインのアルコール, 還元糖, $\mathrm{pH}$, 総酸, 揮発酸, エキス, 灰分及び全窒素は, “Methods for Analysis of Must and Wines”6) に従って分析した。

\section{3. 赤ワインのスペクトル分析}

赤ワインの分析は, 基本的には SOMERS \& EVANS ${ }^{1,2)}$ 及び JACKSON らの方法3) 従った。すべての赤ワイン は分析直前に $0.45 \mu \mathrm{m}$ のメンブランフィルターで濾過 した。吸収スペクトルの測定はすべて $1 \mathrm{~mm}$ あるいは $10 \mathrm{~mm}$ の石英セルを用いて行った。

(a) ワインカラー (wine color, $\mathrm{WC}=\mathrm{A}_{520}$ ) と color density $\left(\mathrm{CD}=\mathrm{A}_{420}+\mathrm{A}_{520}\right)$

赤ワインをそのまま $1 \mathrm{~mm}$ セルに入れて測定するか, あるいは重酒石酸カリウムで飽和した $10 \%$ エタノール 水溶液（pH 3.7）で 20 倍に希釈後 $10 \mathrm{~mm}$ セルを用 いて $520 \mathrm{~nm}$ と $420 \mathrm{~nm}$ の吸収を測定した。前者の場合, 得られた值に 10 倍をかけて吸光度とし, 後者の場合, 得られた值に 20 倍をかけて吸光度とした。これらをワ インの $\mathrm{pH}$ でのワインカラー (WC) とした。

Color density は, ワインの $520 \mathrm{~nm}$ と $420 \mathrm{~nm}$ の吸 光度を加えた值とし, color hue は, $520 \mathrm{~nm}$ の吸光度に 対する $420 \mathrm{~nm}$ のそれの比とした。

(b) $\mathrm{pH} 0.25$ でのワインカラー (wine color in 
acid, $\mathrm{WCA}=\mathrm{A}_{520}$ )

無色のカルビノールベースを赤色のフラビリウムベー スとするために，ワインを $1.0 \mathrm{~N} \mathrm{HCl} \mathrm{で} 20$ 倍に希釈 した後 (ワインの $\mathrm{pH}$ は 0.25 となる), $520 \mathrm{~nm}$ の吸光 度を測定した。得られた吸光度に 20 をかけたものを酸 性でのワインカラー（WCA）とした。なお，ワインを $0.6,0.3,0.1 \mathrm{~N} \mathrm{HCl}$ で 20 倍に希釈したときの $\mathrm{pH}$ は，それぞれ $\mathrm{pH} 0.5, \mathrm{pH} 0.8$ 及び $\mathrm{pH} 1.25$ であった。 (c) 色素重合体力ラー [polymeric pigment color, $\left.\mathrm{PPC}=\mathrm{A}_{520}\left(\mathrm{SO}_{2}\right)\right]$

(a) と同様に 20 倍に希釈したワイン $6.5 \mathrm{ml}$ に $20 \%$ ピロ亜硫酸カリウム溶液 $0.1 \mathrm{ml}$ を加えて 1 分後に, 520 $\mathrm{nm}$ の吸収を測定し，得られた值に 20 をかけたものを 色素重合体カラー（PPC）とした。また， PPC を 5/3 したものを $\mathrm{pH}<1$ での色素重合体カラー (PPCA) とし た。

Table 1 General analysis of red table wines from Cabernet Sauvignon and Muscat Bailey A grapes ${ }^{1}$.

\begin{tabular}{|c|c|c|c|c|c|c|c|c|c|}
\hline \multicolumn{2}{|c|}{$\begin{array}{l}\text { Wine } \\
\text { produ- } \\
\text { ced } \\
\text { (Year) }\end{array}$} & $\begin{array}{l}\text { Reduc- } \\
\text { ig sugar } \\
\text { g/100 ml } \\
\text { (s glucose) }\end{array}$ & $\begin{array}{c}\text { Alcohol } \\
\%\end{array}$ & $\begin{array}{l}\text { Total } \\
\text { acidity } \\
\mathrm{g} / 100 \mathrm{ml} \\
\text { (as tartaric } \\
\text { acid) }\end{array}$ & $\begin{array}{l}\text { Volatile } \\
\text { acidity } \\
\text { g/100 ml } \\
\text { (as acetic } \\
\text { acid) }\end{array}$ & $\begin{array}{l}\text { Ash } \\
\mathrm{g} / \ell\end{array}$ & $\begin{array}{c}\text { Extract } \\
\%\end{array}$ & $\begin{array}{l}\text { Total } \\
\text { nitrogen } \\
\mathrm{mg} / \mathrm{l}\end{array}$ & $\begin{array}{c}\mathrm{SO}_{2} \\
\mathrm{mg} / \ell\end{array}$ \\
\hline \multicolumn{10}{|c|}{ Cabernet Sauvignon } \\
\hline '68 & 3.57 & 0.15 & 11.9 & 0.63 & 0.03 & 3.10 & 3.2 & 165 & $-1-^{3}(12)^{2,4}$ \\
\hline 75 & $3.80(3.87)^{2}$ & 0.20 & 11.8 & 0.54 & 0.04 & 3.10 & 2.5 & 125 & $64 / 16(58)$ \\
\hline 79 & $3.61(3.75)$ & 0.42 & 13.2 & 0.54 & 0.03 & 2.85 & 2.7 & 160 & $35 / 2(19)$ \\
\hline '80 & $3.60(3.69)$ & 0.32 & 12.9 & 0.54 & 0.05 & 2.29 & 2.5 & 103 & $77 / 5(51)$ \\
\hline '81 & $3.68(3.69)$ & 0.06 & 12.2 & 0.50 & 0.05 & 3.00 & 2.7 & 61 & $48 / 14(27)$ \\
\hline '82 & $3.58(3.71)$ & 0.10 & 11.8 & 0.74 & 0.04 & 3.64 & 3.2 & 166 & $86 / 21(49)$ \\
\hline '83 & $3.56(3.70)$ & 0.19 & 12.3 & 0.76 & 0.05 & 2.33 & 2.2 & 84 & $30 / 11(6)$ \\
\hline '84 & $3.67(3.73)$ & 0.18 & 11.6 & 0.46 & 0.04 & 2.63 & 2.6 & 203 & $55 / 9(28)$ \\
\hline '85 & $3.70(3.73)$ & 0.14 & 12.3 & 0.56 & 0.04 & 5.20 & 2.6 & 249 & $67 / 6(40)$ \\
\hline '86 & $3.79(4.03)$ & 0.16 & 11.9 & 0.68 & 0.02 & 3.49 & 3.3 & 194 & $36 / 23(4)$ \\
\hline '87 & $3.80(3.78)$ & 0.19 & 12.8 & 0.54 & 0.02 & 3.28 & 3.1 & 271 & $53 / 15(26)$ \\
\hline '88 & $3.39(3.63)$ & 0.20 & 11.9 & 0.79 & 0.02 & 3.22 & 3.1 & 121 & $27 / 8(6)$ \\
\hline '89 & $3.72(3.83)$ & 0.18 & 11.9 & 0.51 & 0.04 & 1.68 & 1.7 & 143 & $14 / 2(2)$ \\
\hline '90 & $3.75(3.83)$ & 0.37 & 12.1 & 0.53 & 0.05 & 2.86 & 1.5 & 103 & $51 / 36(35)$ \\
\hline '91 & $3.76(3.82)$ & 0.32 & 13.1 & 0.48 & 0.04 & 2.98 & 2.5 & 120 & $29 / 6(26)$ \\
\hline '92 & $3.42(3.56)$ & 0.38 & 12.9 & 0.76 & 0.02 & 2.24 & 2.8 & 164 & $30 / 18(\cdot)$ \\
\hline '93 & $3.48 \cdots$ & 0.18 & 11.6 & 0.81 & 0.03 & 4.47 & 2.9 & 251 & $76 / 71(\cdot)$ \\
\hline \multicolumn{10}{|c|}{ Muscat Bailey A } \\
\hline 75 & $3.80(3.80)$ & 0.03 & 11.9 & 0.69 & 0.05 & 2.90 & 3.0 & 144 & $61 / 19(48)$ \\
\hline '79 & $3.61(3.63)$ & 0.46 & 13.5 & 0.69 & 0.05 & 2.75 & 3.2 & 138 & $\cdot / \cdot(139)$ \\
\hline '80 & $3.60(3.62)$ & 0.11 & 13.0 & 0.70 & 0.02 & 2.85 & 3.1 & 130 & $120 / 29(30)$ \\
\hline '81 & $3.54(3.69)$ & 0.07 & 10.8 & 0.71 & 0.02 & 5.17 & 3.1 & 15419 & $192 / 22(71)$ \\
\hline '82 & $3.45(3.61)$ & 0.12 & 13.7 & 0.73 & 0.02 & 2.61 & 3.0 & 16011 & $119 / 38(63)$ \\
\hline '83 & $3.58(3.69)$ & 0.16 & 13.3 & 0.69 & 0.03 & 2.85 & 3.0 & $167 \varepsilon$ & $89 / 28(61)$ \\
\hline '84 & $3.49(3.54)$ & 0.18 & 13.4 & 0.67 & 0.04 & 2.78 & 3.0 & 145 & $67 / 9(72)$ \\
\hline '85 & $3.80(3.84)$ & 0.25 & 13.8 & 0.48 & 0.06 & 2.42 & 2.6 & 189 & $67 / 5(2)$ \\
\hline '86 & $3.68(3.70)$ & 0.22 & 13.8 & 0.70 & 0.02 & 3.45 & 3.3 & 179 & $54 / 25$ (24) \\
\hline '87 & 3.85 (3.92) & 0.11 & 12.6 & 0.49 & 0.02 & 2.86 & 2.9 & 178 & $72 / 3(59)$ \\
\hline '88 & $3.39(3.57)$ & 0.20 & 12.8 & 0.79 & 0.02 & 2.76 & 2.7 & 148 & $36 / 8(2)$ \\
\hline '89 & $3.35(3.64)$ & 0.24 & 12.0 & 0.74 & 0.08 & 2.86 & 1.6 & 101 & $15 / 2(3)$ \\
\hline '90 & 3.39 (3.39) & 0.07 & 12.2 & 0.63 & 0.08 & 1.78 & 1.5 & 64 & $28 / 7(22)$ \\
\hline '91 & $3.83(3.85)$ & 0.32 & 11.2 & 0.52 & 0.05 & 2.40 & 2.8 & 116 & $29 / 6(23)$ \\
\hline '92 & $3.52(3.56)$ & 0.18 & 12.7 & 0.72 & 0.03 & 2.36 & 2.9 & 171 & $65 / 34(\cdot)$ \\
\hline '93 & $3.34 i-1)$ & 0.36 & 11.2 & 0.92 & 0.04 & 2.51 & 2.7 & 10613 & $137 / 20(-)$ \\
\hline
\end{tabular}

'Analyses were done 8 months after fermentation.

${ }^{2}$ The values in parentheses were analyzed between May and July, 1994.

${ }^{3}$ Total $\mathrm{SO}_{2}$ content/Free $\mathrm{SO}_{2}$ content.

'Total $\mathrm{SO}_{2}$ content.

\section{4. 赤ワインの官能検査}

JACKSON $5^{3)}$ の方法に従って, 1981〜1990 年に醸造 したワイン各 10 点の官能検査を行い，スペクトル分析 で得た色素パラメータとの相関を調べた。最高点は色 (color) 5 点, アロマ (aroma) 5 点, フレーバー（flavor) 10 点とし, 合計 (overall quality) 20 点とした。

\section{実験結果及び考察}

\section{1. 赤ワインの一般分析}

この実験で用いた 17 製造年のカベルネ・ソービニヨ ンワインと 16 製造年のマスカット・ベリーA 発酵終了後 8 カ月目の一般分析結果を Table 1 に示し た。これらの分析值は, 日本産ブドウから常法に従って 製造し， 8 カ月貯蔵した赤ワインとしてごく普通であ り，赤ワインの製造と貯蔵は通常通り進行したと考えら れる。従って, これらの赤ワインは熟成中の色調の変化 を検討するのに適当な試料と認められた。

また， 2 種の赤ワインを約 8 カ月（1993[年 10 月に発酵) 25 年 8 力月（1968 年 10 月に 発酵) 貯蔵した後に，再び $\mathrm{pH}$ 及び亜硫酸含量 を分析したところ（1994年 5 月〜 7 月に分析）, 発酵が終了してから 8 力月後に分析した值と比 ベ, 全亚硫酸含量は非常に減少し, どちらのワ インでも約半分となった。一方, 遊離亜硫酸 は, 1992 年と 1993 年産の若いワインを除い て $10 \mathrm{mg} / \mathrm{l}$ 以下しか存在しなかった。また, ほとんどのワインにおいて，8 月月後に測定し た $\mathrm{pH}$ よりも 1 年 8 力月 25 年 8 力月後の $\mathrm{pH}$ の方が若干高い傾向が認められたが，いく つかのワインではマロラクティック発酵が起こ ったと思われる比較的大きな $\mathrm{pH}$ の上昇があ った。しかし，貯蔵期間の長さと $\mathrm{pH}$ の変化 量との相関関係は認められず, 貯蔵開始後早い 時期に $\mathrm{pH}$ の小さな上昇が起こり, 以後はほ とんど变化しないように思われた。

\section{2. 各種溶液を用いてワインを希勫したとき の $520 \mathrm{~nm}$ での吸光度の変化}

ブドウジュースや若い赤ワインの着色の度合 は, 存在するアントシアニン濃度や共存する他 のワイン成分によって影響され，これらはセル フ・アソシェーション及びュピグメンテーショ ン現象として知られている。

SOMERS and EVANS ${ }^{7)}$ は, ブドウ果皮から 抽出された色素によってマストに呈色する濃い 赤色は, アルュール発酵中に著しく減少する 
横塚：カベルネ・ソービニヨン及びマスカット・ベリーA赤ワインの熟成中における色調の変化 I .

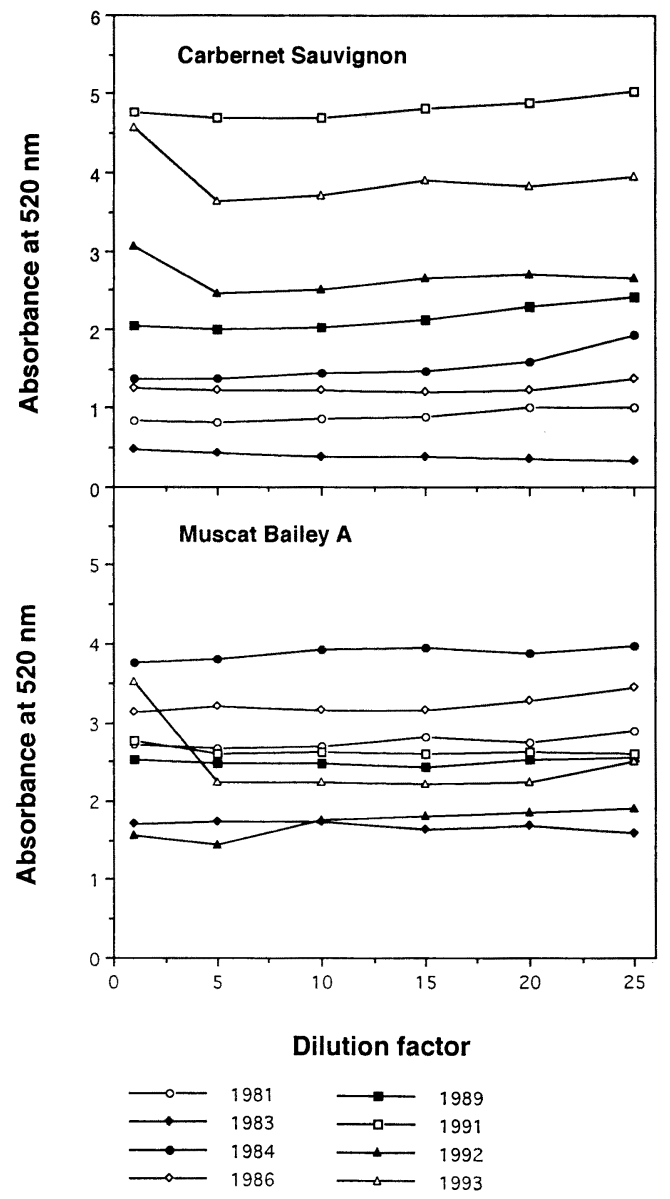

Fig. 1 Effect of dilution on absorbance of red wines at $520 \mathrm{~nm}$.

Red wines were diluted 5 to 25 fold with $10 \%$ aqueous ethanol saturated with potassium hydrogen tartrate $(\mathrm{pH}$ 3.7).

がこれは水素結合を介したセルフ・アソシェーション により強く着色した色素構造が生成したアルコールによ って破壊されたためであると結論した。この濃色効果は 色素濃度依存性と言われているので, 種々の溶液でワイ ンを希釈し，セルフ・アソシェーションやコピグメンテ ーションの影響を検討した。

重酒石酸カリウムで飽和した $10 \%$ エタノール水溶液 （pH 3.7）で 2 種のワインを 5〜25 倍に希釈した後, 520 $\mathrm{nm}$ の吸光度を測定し，得られた測定值にそれぞれの希 釈倍率をかけ，その結果の一部を Fig. 1 に示した。希釈 による $520 \mathrm{~nm}$ の吸光度の減少は, 1992 年と 1993 年産 のカベルネ・ソービニヨン及び 1993 年産のマスカッ ト・ベリー $\mathrm{A}$ の最も若い赤ワインにのみ見られた。これ らの 3 ワインの濃色効果について, ワインを $1 \mathrm{~mm}$ 七 ルで測定して 10 倍したものと， 5 倍に希釈したときの
測定值に 5 をかけた值で比較すると, それぞれ 1.25 (1993年), 1.25 (1992 年), 1.57 (1993 年) 倍となり, SOMERS $^{8)}$ が得た濃色効果よりずっと小さかった。同 様に $420 \mathrm{~nm}$ の吸収を測定したが，いずれのワインでも 濃度効果は小さかった。また, 重酒石酸カリウムで飽和 した $10 \%$ エタノール水溶液の代わりに水を用いて 5〜 25 倍に希釈し, $520 \mathrm{~nm}$ の吸光度を測定したところ, 後 者で希釈したときの值は, 前者で希釈したときの值の, カベルネ・ソービニヨンワインでは平均 1.05 倍, 1975 1990 年産マスカット・ベリーAワインでは平均 1.03 倍, 1992 年と 1993 年産マスカット・ベリーAワインで は平均 1.24 倍となった。水で希釈したときの試料の $\mathrm{pH}$ と希釈前のワインの $\mathrm{pH}$ との差は $0.1 \sim 0.25$ の範 囲にあり, 若いワインよりも熟成したワインの場合に差 が小さい傾向が認められた。本研究で用いた赤ワインを スペクトル分析する場合, $1 \mathrm{~mm}$ セルを用いて測定した 非希釈ワインの $520 \mathrm{~nm}$ の吸光度と, $10 \mathrm{~mm}$ セルを用い て測定した希釈ワインの $520 \mathrm{~nm}$ の吸光度 (七ル厚と希 釈倍率とを補正後）との間には大きな差異はなかった。 また, SOMERS \& EVANS ${ }^{7)}$ が報告したエタノールの 存在による $520 \mathrm{~nm}$ の吸光度の減少は, 本実験では最も 若いワイン以外には顕著には認められなかった。これら の理由の一つとして，ここで用いたワインに含まれてい た色素含量がかなり少なく, SOMERS \& EVANS ${ }^{7)}$ の用 いたワインのそれの数分の 1 であり, ワイン中で分子内 あるいは分子間の会合によって大きな色素会合体ができ にくく, セルフ・アソシェーション効果などで濃い着色 をできなかったためではないかと思われる。

アントシアニンはワインの $\mathrm{pH}$ では赤色のフラビリ ウムカチオンと無色のカルビノールベース及びキノイダ ルベースが主な形であり，これらが平衡となっている が， $\mathrm{pH}$ が低下するとともにフラビリウム形が増加する ことが知られている。 SOMERS ${ }^{4)}$ は, 全ブドウアントシ アニンカラーと赤ワインからイソアミルアルコールでア ントシアニンモノマーを抽出除去した後の水層中の色素 重合体カラーを pH 0.75〜4.76 の間で測定した。その 結果に基づいてワイン中の全アントシアニン含量はワイ ンの $\mathrm{pH}$ を 1 以下にして测定した $520 \mathrm{~nm}$ の吸光度か ら求めることができることを報告した4。。しかし，本実 験を行っている途中で, 単にワインの $\mathrm{pH}$ を 1 以下にす るという条件では， $520 \mathrm{~nm}$ の吸光度が一定の值をとら ないことを見いだしたので， pH 0.25〜1.25 に調整した ワインの $520 \mathrm{~nm}$ の吸収值 $\left(\mathrm{A}_{520}\right)$ を調べて, $\mathrm{pH}$ と $\mathrm{A}_{520}$ との関連を全ワイン試料について調べた。その結果の一 部を Fig. 2 に示した。pH 0.80 での $520 \mathrm{~nm}$ の吸収值 に対する $\mathrm{pH} 0.25$ でのそれの比，すなわち $\mathrm{A}_{520}(\mathrm{pH}$ 
横塚：カベルネ・ソービニヨン及びマスカット・ベリーA赤ワインの熟成中における色調の変化 I .

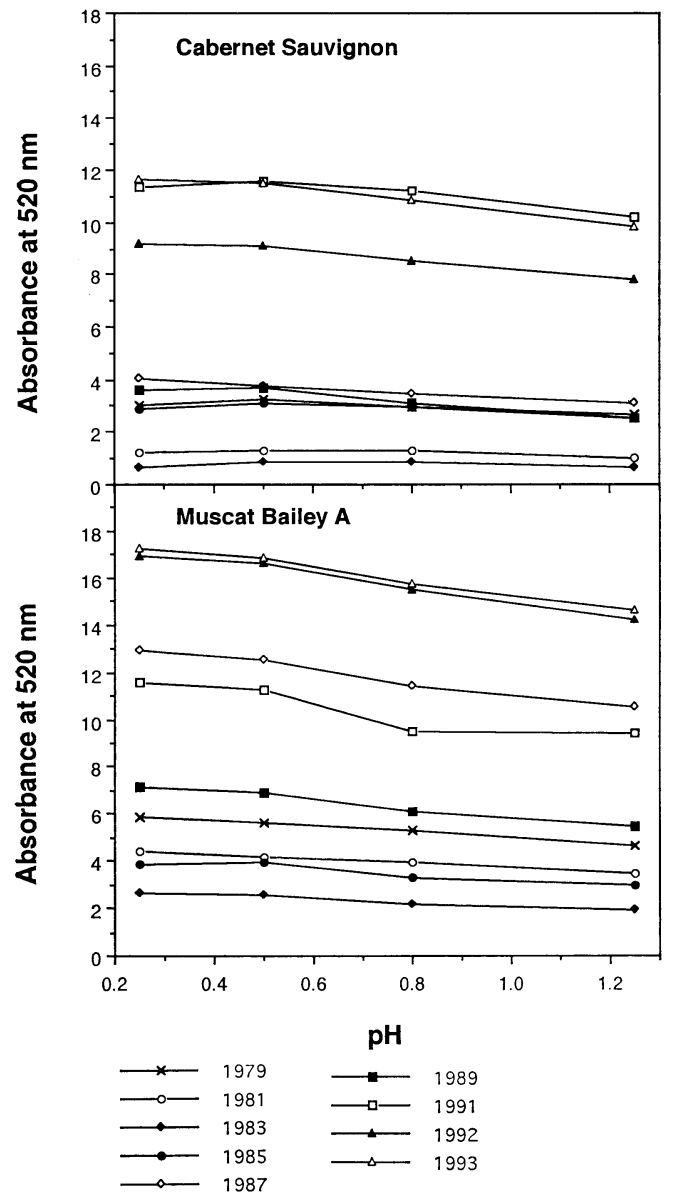

Fig. 2 Effect of $\mathrm{pH}$ in the range 0.25 to 1.25 on absorbance of red wines at $520 \mathrm{~nm}$.

When red wines were diluted 20 fold with $0.1,0.3$, 0.6 and $1.0 \mathrm{~N} \mathrm{HCl}$, the pHs were $1.25,0.8,0.5$ and 0.25 , respectively.

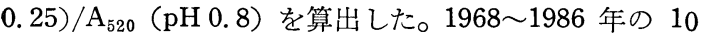
点の熟成したカベルネ・ソービニヨンワインの場合の同 比は平均 $0.96,1987 \sim 1993$ 年のより新しい7 点のワイ ンの場合の同比は 1.13 であるのに対して, マスカット・ ベリーA 囲にあり, 平均 1.15 であった。このことは, いずれの ワインでもそれらの $\mathrm{pH}$ が $0.5 \sim 0.8$ 程度では, 存在す るすべてのアントシアニンや恐らく色素オリゴマーある いはポリマーをカチオンにすることはできないと考えら れる。一方, $\mathrm{pH} 0.25$ ではほぼすべてのアントシアニン がカチオンに変わっているのではないかと推定された。 以上の結果から, SOMERS \& EVANS ${ }^{1,2)}$ や JACKSON らのように, $\mathrm{pH}<1$ でのワインカラーといら表現では 不十分で, 測定する $\mathrm{pH}$ を定めることが重要と思われ た。

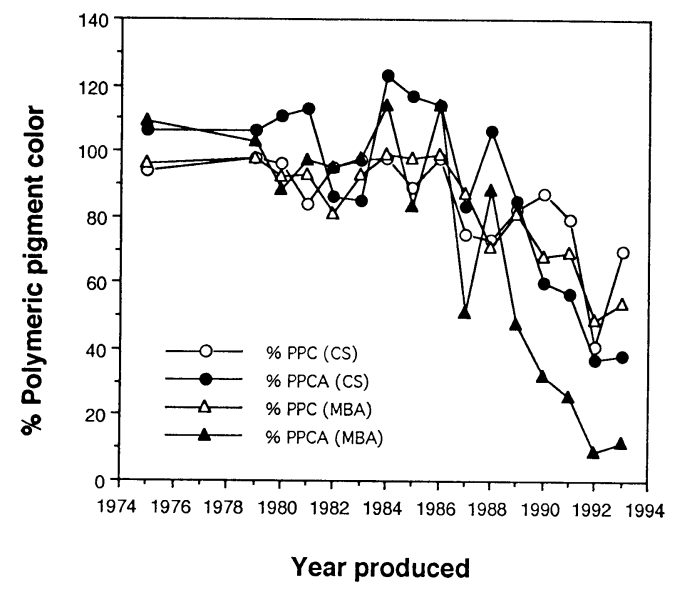

Fig. 3 Contribution of polymeric pigment color (PPC) [or polymeric pigment color in acid (PPCA)] to wine color at wine $\mathrm{pH}$ (WC) [or to wine color in acid (WCA)].

Polymeric pigment colors were estimated according to the method of Somers and Evans ${ }^{1)}$. Polymeric pigment color ( $\mathrm{PPC}$ ) at wine $\mathrm{pH}$ is the remaining $\mathrm{A}_{520}$ after decolorization of the wine by the addition of $\mathrm{SO}_{2}$ at $\mathrm{pH}$ 3.7. Polymeric pigment color in acid is $5 / 3 \times \mathrm{PPC}$.

以上の肴釈实験から，ワインの色調を $520 \mathrm{~nm}$ で測定 する際に，ワインを希橎したり異なった $\mathrm{pH}$ で測定する と, 若いワインと熟成したワインではそれらの影響の度 合がかなり違うことが明らかとなった。そこで, 若いワ インにおいてもセルフ・アソシェーションやコピグメン テーション効果がでない十分に希釈した試料をスペクト ル分析する方が再現性のある結果を与兄ると思われたの で，以後の分析では，ワインを 20 倍に希釈した試料の $520 \mathrm{~nm}$ の吸光度を $10 \mathrm{~mm}$ セルを用いて測定すること とした。

アントシアニンモノマーや色素オリゴマーの一部は, ワインの $\mathrm{pH}$ で過㮃の亜硫酸の添加によって漂白され, 一方, 亜硫酸によっても脱色されにくいカラーは色素重 合体であることが知られている。後者のカラー強度は $\mathrm{pH}<1$ にすると経験的にワインの $\mathrm{pH}$ でのそれの $5 / 3$ 倍になると報告されている4。 ワインの $\mathrm{pH}$ でのワイン カラー (WC) に占める色素重合体カラーの割合 (PPC $\times 100 / \mathrm{WC}=\mathrm{A} \%)$ と全アントシアニンカラー $(\mathrm{WCA})$ に 占める $\mathrm{pH}<1$ 以下での色素重合体カラー（PPCA）の 割合 $(\mathrm{PPCA} \times 100 / \mathrm{WCA}=\mathrm{B} \%)$ を求め, その結果を Fig. 3 に示した。カベルネ・ソービニヨンのワインの $\mathrm{pH}$ での色素重合体の割合（A）とマスカット・ベリー Aワインのそれは非常に似た傾向を示し，また $\mathrm{pH}<1$ での色素重合体の割合（B）でも両品種のワインで類似 の曲線が認められた。Fig. 3 の 4 本のグラフから総合的 
横塚：カベルネ・ソービニヨン及びマスカット・ベリーA赤ワインの熟成中に拈ける色調の変化 I .

Table 2 Spectral analysis of Cabernet Sauvignon and Muscat Bailey A red wines.

\begin{tabular}{|c|c|c|c|c|c|c|c|c|c|}
\hline \multirow{2}{*}{$\begin{array}{l}\text { Wine } \\
\text { (Year) } \\
\text { Cabern }\end{array}$} & $\begin{array}{l}W C^{1} \\
\left(A_{520}\right)\end{array}$ & \multirow[t]{2}{*}{$\begin{array}{c}C D^{2} \\
\left(A_{520}+A_{420}\right)\end{array}$} & \multicolumn{2}{|c|}{$\begin{array}{l}P C^{3} \\
\left(A_{520}\right)\end{array}$} & \multicolumn{2}{|c|}{$\begin{array}{c}\mathrm{CH}^{4} \\
\left(\mathrm{~A}_{420} / \mathrm{A}_{520}\right)\end{array}$} & \multicolumn{2}{|c|}{$\begin{array}{l}W C A^{5}\left(A_{520}\right. \\
\text { at } p H 0.25)\end{array}$} & \multirow[t]{2}{*}{$\begin{array}{l}\mathrm{PPCA}^{6} \\
(\mathrm{PPC} \times 5 / 3)\end{array}$} \\
\hline & et Sauvigno & & & & & & & & \\
\hline '68 & 1.56 & 3.52 & 1.40 & & 1.41 & & 2.38 & & 2.33 \\
\hline$' 75$ & $1.38^{7}(1.72)^{8}$ & $3.24(3.90)$ & 1.30 & (1.49) & 1.53 & (1.27) & 2.04 & (2.41) & 2.17 \\
\hline '79 & $1.94(2.45)$ & $4.44(4.78)$ & 1.90 & (2.33) & 1.22 & $(0.95)$ & 3.00 & $(3.80)$ & 3.17 \\
\hline '80 & $1.94(2.10)$ & $3.96(4.25)$ & 1.86 & (1.83) & 1.04 & (1.02) & 2.80 & (3.38) & 3.10 \\
\hline '81 & $1.00(1.69)$ & $2.72(3.53)$ & 0.84 & (1.49) & 1.72 & $(1.09)$ & 1.24 & $(2.80)$ & 1.40 \\
\hline '82 & $0.42(0.66)$ & $1.22(1.49)$ & 0.40 & $(0.58)$ & 1.90 & $(1.26)$ & 0.78 & (1.11) & 0.67 \\
\hline '83 & $0.36(0.53)$ & $1.40(1.55)$ & 0.35 & $(0.45)$ & 2.89 & (1.92) & 0.68 & $(0.86)$ & 0.58 \\
\hline '84 & $1.62(1.52)$ & $3.26(2.90)$ & 1.58 & $(1.36)$ & 0.84 & (0.91) & 1.98 & (2.55) & 2.63 \\
\hline '85 & $2.20(2.10)$ & $6.22(4.22)$ & 1.96 & $(1.79)$ & 0.95 & (1.01) & 2.92 & (3.63) & 3.26 \\
\hline '86 & $1.24(1.64)$ & $2.50(3.19)$ & 1.22 & $(1.48)$ & 1.02 & (0.95) & 1.78 & (2.82) & 2.03 \\
\hline '87 & $2.68(3.05)$ & $5.04(6.02)$ & 2.02 & (1.60) & 0.88 & (0.97) & 4.08 & (7.74) & 3.37 \\
\hline '88 & $2.06(1.52)$ & $4.62(3.06)$ & 1.50 & (1.22) & 1.24 & (1.20) & 2.36 & (2.28) & 2.50 \\
\hline '89 & $2.28(2.09)$ & $4.70(4.13)$ & 1.86 & (1.41) & 1.06 & $(0.98)$ & 3.64 & $(6.06)$ & 3.10 \\
\hline '90 & $2.32(1.57)$ & $4.72(3.29)$ & 2.02 & (1.12) & 1.03 & (0.91) & 5.58 & (11.91) & 3.37 \\
\hline '91 & $4.88(3.91)$ & $9.04(6.79)$ & 3.87 & (1.49) & 0.85 & $(0.74)$ & 11.36 & (26.77) & 6.45 \\
\hline '92 & 2.70 & 4.84 & 2.02 & & 0.79 & & 9.16 & & 3.37 \\
\hline '93 & 3.84 & 6.48 & 2.68 & & 0.69 & & 11.64 & & 4.47 \\
\hline$r^{9}$ & $0.907^{\star \star *}$ & $0.845^{* * *}$ & & 517 & & 0 & & Jo & \\
\hline
\end{tabular}

\begin{tabular}{|c|c|c|c|c|c|c|c|c|}
\hline \multicolumn{9}{|c|}{ Muscat Bailey A } \\
\hline '75 & $2.80^{1}(3.04)^{2}$ & $6.34(6.65)$ & 2.70 & (2.86) & 1.35 & (1.19) & $(4.71)$ & 4.50 \\
\hline '79 & $3.68(4.22)$ & $7.94(8.41)$ & 3.62 & (3.82) & 1.09 & (0.99) & $(6.90)$ & 6.03 \\
\hline '80 & $2.62(2.88)$ & $5.78(5.83)$ & 2.42 & (2.48) & 1.24 & $(1.02)$ & $4.56 \quad(5.17)$ & 4.03 \\
\hline '81 & $2.74(2.75)$ & $5.72(5.89)$ & 2.56 & (2.24) & 1.09 & (1.14) & $4.42 \quad(4.99)$ & 4.27 \\
\hline '82 & $1.08(1.19)$ & $2.12(2.42)$ & 0.88 & (1.05) & 0.96 & $(1.03)$ & $1.54(1.86)$ & 1.47 \\
\hline '83 & $1.68(1.74)$ & $3.52(3.63)$ & 1.56 & (1.53) & 1.09 & (1.09) & $2.66 \quad(2.88)$ & 2.60 \\
\hline '84 & $3.88(4.47)$ & $6.74(7.78)$ & 3.86 & (3.99) & 0.75 & $(0.74)$ & 5.64. (7.43) & 6.43 \\
\hline '85 & $1.88(2.18)$ & $4.46(4.73)$ & 1.84 & (1.67) & 1.37 & (1.17) & $3.68 \quad(4.88)$ & 3.07 \\
\hline '86 & $3.28(3.90)$ & $6.38(7.68)$ & 3.26 & (3.26) & 0.95 & $(0.97)$ & $4.78 \quad(7.88)$ & 5.43 \\
\hline '87 & $4.50(5.02)$ & $8.32(9.32)$ & 3.90 & (3.73) & 0.85 & $(0.86)$ & $12.86(20.86)$ & 6.50 \\
\hline '88 & $1.32(2.04)$ & $3.06(4.35)$ & 0.94 & (1.29) & 1.32 & (1.13) & $1.78(3.50)$ & 1.57 \\
\hline '89 & $2.54(3.04)$ & $4.80(5.47)$ & 2.06 & (2.06) & 0.89 & $(0.80)$ & $7.14(14.67)$ & 3.43 \\
\hline '90 & $1.12(2.45)$ & $2.02(3.81)$ & 0.76 & $(1.06)$ & $0: 80$ & $(0.74)$ & $3.96 \quad(9.49)$ & 1.27 \\
\hline '91 & $2.62(4.16)$ & $4.84(7.24)$ & 1.82 & (1.57) & 0.85 & $(0.74)$ & $11.60(17.98)$ & 3.03 \\
\hline '92 & 1.86 & 3.18 & 0.92 & & 0.71 & & 16.94 & 1.53 \\
\hline '93 & 2.24 & 3.76 & 1.20 & & 0.68 & & 17.24 & 2.00 \\
\hline & $0.913^{\star * *}$ & $0.936^{\star * *}$ & & 02 & & 195 & $0.950^{\star \star \star}$ & \\
\hline
\end{tabular}

${ }^{2}$ Color density.

${ }^{3}$ Polymeric pigment color.

${ }^{4}$ Color hue.

${ }^{5}$ Wine color in acid (at pH 0.25).

${ }^{6}$ Polymeric pigment color in acid.
${ }^{1}$ Wine color at $\mathrm{pH} 3.7$.

\author{
${ }^{7}$ Measured between May and July, 1994. \\ ${ }^{8}$ Measured between May and July, 1992. \\ ${ }^{9}$ Correlation coefficient $(r)$ \\ Confidence limits: \\ $r(\phi=12, p=0.05)=0.5324\left(^{*}\right)$ \\ $r(\phi=12, p=0.01)=0.6614(* *)$ \\ $r(\phi=12, p=0.001)=0.7800\left(^{\star \star \star}\right)$
}

に推察すると，1986 年以前に製造したワインの色調は 汪とえど色素オリゴマーあるいはポリマーのカラーに依 存し，一方，1989 年以降製造した若いワインのカラー はモノマー,オリゴマー,ポリマーが混ざったカラーで あると推定された。

\section{3. 製造年の異なるワインを分析する意義}

赤ワインの色調の熟成中の変化に関する研究を進める 西たって，同じ製造年のワインを貯蔵し，以後毎年そ のワインの分析を続ける方法と，買なった製造年のワイ ンを同じ条件で眝蔵し，すべての試料ワインを同時に分 析する方法がある。前者は同一の試料から出発すること 飞優れているが，長期にわたって同じ実験者が同一の側 定機器や試薬を使って分析することは難しいので，毎年 得られるデータを比較することに問題がある。一方, 後 者は分析の信頼性に利点はあるが, 同一の試料の経時変
化を調べられないので, 製造年によってブドウ の品質,つまりワイン成分が異なるために熟成 経過がワインによって違う懸念がある。そこ で，1975〜1990 年に製造したカベルネ・ソー ビニヨン及びマスカット・ベリーAワイン各 14 点, 合計 28 点を用いて, 1992 年と 1994 年の 5 月〜 7 月に各ワインの色調についてスペ クトル分析を行って, 2 年間の各ワインの色素 パラメータの変化を比較した。Table 2 はその 結果を示したものである。その結果，2種のワ インの WC, CD，PPC 及び WCA に関して, カベルネ・ソービニヨンワインの PPC を除い たいずれのパラメータにおいても高い相関が得 られた。これらのことから, 熟成の程度の異な る製造年の違うワインでも 2 年間の色素パラメ 一タの変化の度合には大きな差異はないことが 分かった。従って, 本研究では, 製造年の違い による原料ブドウの品質の差異に問題は残る が, 実験計画の設定が容易で, かつ分析上信頼 性のある後者の方法を採用することによって， 熟成の経過を調べることが可能であるとの結論 に達した。

\section{4. 色素パラメータのスベクトル分析}

1980 年以降の異なった年度に製造された 2 種のワインの原料ブドウは, 同じブドウ園で栽 培されたものであり，また栽培法や製造法も毎 年同様に行っているので, ここで得られた $\mathrm{pH}$ 3.7 及び $\mathrm{pH} 0.25$ でのワインカラーの製造年 による差異は, それぞれの年の気候の相違によ るものと推定される。例えば, 1987 年産カべ ルネ・ソービニヨンワインのワインカラーはそ の前後の年のワインのワインカラーと比べて高いが, 同 じ年のマスカット・ベリーAワインでも同様なことが見 られ，1987 年が色素生成の観点から見てブドウ生育の 適当な年であったことが推定された。それぞれの製造年 のワインに含まれている全アントシアニン量は $\mathrm{pH} 0.25$ でのワインカラーから容易に比較でき, 1987 年産ワイ ンを特例とすれば，ぞちらの品種のワインでも製造後約 5 年で全アントシアニンは注注一定值に達するように思 われた。ワインを $\mathrm{pH} 3.7$ から $\mathrm{pH} 0.25$ 亿と酸性化す ることによる $520 \mathrm{~nm}$ の吸光度の增加は, カベルネ・ ソービニョンワインで 1.14 3.03 倍, マスカット・ベ リーAワインで 1.35〜9.70 倍であった。

Color hue $\left(\mathrm{A}_{420} / \mathrm{A}_{520}\right)$ はワインの熟成 (酸化)の程度 を測る一つの尺度として知られ，この值が 1 を越えれば 熟成したワインと見なされる ${ }^{2,9,10)}$ 。Table 2 と Fig. 3 を 
参考に，仮に 1989１993 年の若いワインを熟成途中の ワインとし，それよりも古いワインを熟成したワインと して二つのグループに分け，それぞれの平均の color hue を算出すると, 若いカベルネ・ソービニヨンワイン の color hue は 0.88 , 熟成ワインのそれは 1.39 , 若い マスカット・ベリーAワインの color hue は 0.79 , 熟 成ワインのそれは 1.10 であった。いずれの值もマスカ ット・ベリーAワインの方がカベルネ・ソービンヨンワ

Table 3 Taster's scores for Cabernet Sauvignon and Muscat Bailey A aged red wines produced from 1981 to 1990.

\begin{tabular}{|c|c|c|c|c|}
\hline Year produced & $\begin{array}{l}\text { Color } \\
(0-5)\end{array}$ & $\begin{array}{c}\text { Aroma } \\
(0-5) \\
\end{array}$ & $\begin{array}{l}\text { Flavor } \\
(0-10)\end{array}$ & $\begin{array}{c}\text { Overall quality } \\
(0-20)\end{array}$ \\
\hline \multicolumn{5}{|c|}{ Cabernet Sauvignon } \\
\hline '81 & 2.4 & 2.7 & 4.8 & 9.9 \\
\hline '82 & 1.5 & 1.7 & 3.0 & 6.2 \\
\hline '83 & 1.3 & 1.7 & 2.6 & 5.6 \\
\hline '84 & 3.4 & 3.2 & 5.6 & 12.2 \\
\hline '85 & 3.2 & 2.9 & 6.8 & 12.9 \\
\hline '86 & 3.1 & 2.3 & 5.8 & 11.2 \\
\hline '87 & 4.4 & 3.2 & 7.0 & 14.6 \\
\hline '88 & 2.6 & 1.9 & 3.6 & 8.1 \\
\hline '89 & 3.5 & 3.1 & 6.2 & 12.8 \\
\hline '90 & 3.9 & 3.5 & 6.0 & 13.4 \\
\hline \multicolumn{5}{|l|}{ Muscat Bailey A } \\
\hline '81 - & 3.3 & 3.2 & 5.2 & 11.7 \\
\hline '82 & 2.4 & 2.6 & 4.2 & 9.2 \\
\hline '83 & 2.5 & 2.5 & 4.6 & 9.6 \\
\hline '84 & 4.0 & 3.2 & 5.5 & 12.7 \\
\hline '85 & 3.0 & 3.2 & 5.2 & 11.4 \\
\hline '86 & 3.9 & 2.7 & 5.4 & 12.0 \\
\hline '87 & 4.0 & 3.7 & 5.6 & 13.3 \\
\hline '88 & 3.2 & 2.4 & 4.4 & 10.0 \\
\hline '89 & 3.8 & 3.4 & 5.4 & 12.6 \\
\hline '90 & 2.5 & 3.3 & 4.6 & 10.4 \\
\hline
\end{tabular}

Table 4 Linear correlation coefficients between quality attributes and analytical parameters for aged red wines.

\begin{tabular}{|c|c|c|c|c|}
\hline \multirow[b]{2}{*}{ Parameter } & \multicolumn{3}{|c|}{ Correlation coefficients (r) } & \multirow[b]{2}{*}{ Overall quality } \\
\hline & Color & Aroma & Flavor & \\
\hline \multicolumn{5}{|l|}{ Cabernet Sauvignon } \\
\hline Color & - & - & - & - \\
\hline Aroma & $0.7099 *$ & - & - & - \\
\hline Flavor & $0.9154^{\star \star \star}$ & 0.5010 & - & - \\
\hline Overall quality & $0.9818^{\star \star}$ & 0.7356 & $0.9476^{\star \star \star}$ & - \\
\hline Wine color $\left(A_{520}\right)$ & $0.8678^{\star \star \star *}$ & 0.5967 & $0.8701 * *$ & $0.8871^{\star \star \star}$ \\
\hline Color density $\left(A_{520}+A_{420}\right)$ & $0.8450^{*}$ & 0.5718 & $0.8503^{* *}$ & $0.8631^{\star *}$ \\
\hline Polymeric pigments $\left(A_{520}\right)$ & 0.7450 * & 0.5800 & $0.8597 * *$ & $0.8367^{\star \star}$ \\
\hline Color hue $\left(A_{420} / A_{520}\right)$ & $0.7994^{\star \star}$ & 0.5992 & $0.7975^{* *}$ & $0.8270^{* *}$ \\
\hline Wine color in acid $\left(A_{520}\right)$ & $0.7752^{\star \star}$ & 0.5505 & $0.6380^{*}$ & $0.7239 *$ \\
\hline \multicolumn{5}{|l|}{ Muscat Bailey A } \\
\hline Color & - & - & - & - \\
\hline Aroma & 0.3130 & - & - & - \\
\hline Flavor & $0.7443^{*}$ & $0.7642^{*}$ & - & - \\
\hline Overall quality & $0.8331^{\star *}$ & $0.7589^{*}$ & $0.9778^{\star * *}$ & - \\
\hline Wine color $\left(A_{520}\right)$ & $0.8866^{\star \star \star *}$ & 0.4539 & $0.7134^{*}$ & $0.8118^{* \star}$ \\
\hline Color density $\left(A_{520}+A_{420}\right)$ & $0.9121^{\star \star \star}$ & 0.4159 & 0.7273 * & $0.8179^{\star \star}$ \\
\hline Polymeric pigments & $0.8786^{\star \star \star}$ & 0.2408 & 0.6017 & $0.6979 *$ \\
\hline Color hue $\left(A_{420} / A_{520}\right)$ & 0.3701 & 0.3728 & 0.3536 & 0.4147 \\
\hline Wine color in acid & 0.6276 & $0.7969^{* *}$ & $0.8860^{* * *}$ & $0.8854^{\star * \star *}$ \\
\hline
\end{tabular}

Confidence limits:

$\mathrm{r}(\phi=8, \mathrm{p}=0.05)=0.6319\left(^{*}\right)$

$r(\phi=8, p=0.01)=0.7646\left({ }^{* *}\right)$

$r(\phi=8, p=0.001)=0.8721\left(^{\star \star *}\right)$
インよりも低く，色調はマスカット・ベリーAワインの 方がより安定していることが示された。

5. 色素パラメータとワインの官能検査結果との関連

Table 3 は 1981〜1990 年の 10 年間に製造されたカ ベルネ・ソービニヨン及びマスカット・ベリー A赤ワイ ンについて 1992 年に官能検査を行った結果である。 2 種のワインはほぼ同様な評価点となったが，1981～1983 年に製造し，長期間熟成したワインよりも比較的に新し いワインの方が高い評価を受けた。日本産ブドウから製 造した赤ワインは, 製造後数年のものが最も良く, 長く 熟成しても品質がそれほど改善されないという一般的な 評価と一致した。このような官能検査結果と色素パラメ 一タとの相関関係を示したのが Table 4 である。 4 種の 官能評洒点と多くの色素パラメータとの間には良好な直 線的相関がある。特にワインを肉眼で見たとき（color） の評価と, ワインカラー, color density, 色素重合体カ ラーなどの色素パラメータや overall quality とは密接な 関連があった。このことは, 少なくても熟成した赤ワイ ンに関して，消費者がその色調を肉眼的に観察すること によって，一方，分析者は色調に関するいくつかのパラ メータを测定することによって赤ワインの全体の品質を 推定できることを意味する。

\section{要 約}

1. 1968～1993 年に製造したカベルネ・ソービニヨ ン赤ワイン 17 点及びマスカット・ベリー $\mathrm{A}$ 赤ワイン 16 点を 1.8 lガラスボトルに入れ, $15^{\circ} \mathrm{C}$ で約 8 力 月〜25 年 8 力月間貯蔵後, スペクトル分析及 び官能検查を行った。

2. 1975～1990年に製造した 2 種のワイン各 14 点, 計 28 点について, ワインの $\mathrm{pH}$ ある いは $\mathrm{pH}<1$ でのワインカラー, color density, 色素重合体カラー, color hue を 1992 年と 1994 年に测定し， 2 年間経過後の変化量を調 ベた。各色素パラメータの両年の測定值の間で 相関係数を求めてみると，いずれのパラメータ においても高い相関関係が得られ，熟成の程度 の異なる製造年の違らワインでも 2 年間の色素 パラメータの変化の度合はほぼ同じであった。

3. 過剩の亚硫酸添加によりアントシアニン モノマーを脱色して色素重合体カラーを求め, 全アントシアニンカラーに占める色素重合体カ ラーの割合を算出した。その結果, 1986 年以 前に製造した熟成したワインの色調は色素重合 体カラーに大部分由来し，1989１993 年の若 いワインには明らかにモノマーに由来するカラ 
一が存在した。color hue の分析結果を合わせて考える と, これらの 2 種のワインは, 少なくても色調に関する 限り, 製造後約 5 年以内にある熟成状態に達すると考兄 られる。

4. 1981〜1990 年に製造されたワインの官能検査を 行い,その結果と色素パラメータとの関連を調べた。2 種のワインともに熟成したワインよりも若いワインの方 が官能検查で高い評価を受け，また肉眼で観察した色調 (color) の評価とワインカラー, color desity, 色素重合 体カラー, overall quality などのパラメータと密接な相 関がみられた。

以上の結果, 赤ワインの品質を評価するにあたって, 肉眼的にワインの色調を観察することと簡単なスペクト ル分析により色素パラメータを測定することは, 単にワ インの色調の分析に役立つばかりか, ワインの品質全体 を評価するのにきわめて重要であることが分かった。

\section{謝辞}

本研究の一部は本学大学院生, 中沢和生氏並びに保坂 徹氏の助力の下に行われた。ここで謝意を表します。

\section{文献}

1) T.C.SOMERS and M.E.Evans : J. Sci. Food Agric., 25, 1369 (1974)

2) T.C. SOMERS and M.E.Evans : J. Sci. Food Agric., 28, 279 (1977)

3) M. G. JACKSON, C. F. TIMBERLAKE, P. BRIDLE and L. VAlLIS: J. Sci. Food Agric., 29, 715 (1978)

4) T.C. SOMERS : Phytochemistry, 10, 2175 (1971)

5）横塚 勇：山梨大的研報告, 1, 63 (1954)

6) M.A.AMERINe, C.S. OUgh : Methods for $A$ nalysis of Must and Wines, John Wiley \& Sons, Inc., New York (1980)

7) T.C.SOMERS and M.E. EvANS : J. Sci. Food Agric., 30, 623 (1979)

8) T.C. SOMERS : Proc. Sixth Aust. Wine Ind. Tech. Conf., 14-17, July 1986, Adelaide, SA, Australia, Australian Wine Research Institute and Australian Society of Viticulture and Oenology (1987)

9) P.SUdRA Ud : Ann.Technol. Agr., 7, 203 (1958)

10) P. RIBEREAU-GAYON : Chemistry of winemaking (ed. by A. D. Webb), p.50, Am. Chem. Soc., Washington, D.C. (1974) 